\title{
Large chorangiomas: a seven years study in a tertiary care obstetrics and gynaecology hospital
}

\author{
Balamurugan V., Revathy M., Kanchana M. P.*, Shobha S.
}

Department of Pathology, Institute of Obstetrics and Gynaecology, Madras Medical College, Chennai, Tamil Nadu, India

Received: 26 February 2019

Accepted: 02 April 2019

*Correspondence:

Dr. Kanchana M. P.,

E-mail: mpkanchana@rediffmail.com

Copyright: (c) the author(s), publisher and licensee Medip Academy. This is an open-access article distributed under the terms of the Creative Commons Attribution Non-Commercial License, which permits unrestricted non-commercial use, distribution, and reproduction in any medium, provided the original work is properly cited.

\begin{abstract}
Background: Chorangioma is a benign vascular placental tumour. It is composed of fetal capillary proliferation within the chorionic villi supported by a variable stroma. Smaller lesions are incidental, are often missed and carry no clinical significance. Larger lesions are associated with feto-maternal complications and are infrequently sent for histopathological examination.

Methods: The study was conducted at the department of pathology, at a tertiary care obstetrics and gynaecology hospital. The study was a retrospective study which covered 7 years. Paraffin embedded blocks of placental specimens containing mass were taken up for the study. Sections were stained with haematoxylin and eosin (H and E). The results are compared and correlated with clinicopathologic factors. The statistical data are analysed manually. Results: A total of seven cases were included in the study, 4 cases were primi gravida, 1 case each in second, third and fourth gravida. Pregnancy outcome was intrauterine death in 1 case, dead born in 1 case, alive healthy children in 5 cases, birth weight was normal in 4 children, low birth weight in 2 children and 1 was extremely low birth weight. Of the total of 7 placental specimens 3 showed extraplacental mass and rest 4 showed intraplacental mass. All cases showed solitary lesions and measured $>5 \mathrm{~cm}$ (large). Histopathological examination of all 7 specimens showed features of chorangioma.

Conclusions: Careful inspection of the placenta is necessary following all deliveries. Any suspicious lesions should be documented and evaluated by histopathological examination there by predicting feto maternal complications and help the clinicians in better management of the mother and child accordingly. Meagre documentation of such cases prompted us to present this series of 7 cases of large chorangiomas with a mixed fetal outcome.
\end{abstract}

Keywords: Capillary proliferation, Chorangioma, Fetal and maternal complication, Placenta

\section{INTRODUCTION}

Chorangioma is a rare primary vascular tumour of placenta. Incidence is about $1 \%$ of carefully examined term placenta. ${ }^{1}$ Chorangioma is the most common benign tumour of placenta. ${ }^{2}$ It is a hemangioma, similar to those occurring at other body sites. Though chorangioma is the most common tumour of the placenta, tumours arising from placenta are as such rare. It commonly occurs in individuals more than 30 years of age, primi gravida and frequently in twin gestations. The exact aetiology is largely unknown. It presents commonly as a single lesion or occasionally as multiple nodules. They are usually solitary, small, seen within the substance of the placenta and are likely to be discovered as incidental finding or it can present as multiple nodules. The size of the tumour varies from few millimetres to larger lesions weighing more than $1500 \mathrm{~g}$. Large chorangiomas (size more than $5 \mathrm{~cm}$ ), usually appear as bulging protruberance on the fetal surface of the placenta, which may distort the chorionic plate of the placenta or occasionally may be seen on the maternal surface and some can be seen 
attached to the placenta by a thin vascular pedicle. ${ }^{3}$ The clinical significance of such lesions is related to size of the tumour. Smaller lesions are usually asymptomatic, while larger chorangiomas, likely have an increased incidence of maternal, fetal and neonatal complications. Larger lesions can be diagnosed in antenatal period by either colour doppler or ultrasonogram. ${ }^{4}$ The term chorangiomatosis, refers to diffuse involvement of the placenta by the hemangiomatous tissue.

\section{METHODS}

This is a retrospective study conducted at the Department of Pathology, Institute of Obstetrics and Gynaecology, Madras Medical College, Chennai. The study period was 7 years from January 2010 to December 2016. A total of seven cases of placental chorangiomas had been reported. Case details like age of the mother, order of pregnancy, gestational age, mode of delivery, indications for delivery, pregnancy outcome and birth weight of the children were obtained. Also details of relevant investigations, procedure done, nature and gross features of the specimens and histopathological diagnosis of the tissues were obtained from pathology registers.

All placental specimens with mass were included for the study and placental specimens received for other pathological conditions were excluded from the study. Haematoxylin and Eosin stained sections of the paraffin blocks of the representative cases were reviewed.

\section{RESULTS}

A total of 7 cases were analysed. The clinical parameters of the cases were summarized in Table 1 . The mean age of the patients is 28 years (range 22 to 35 years). Five patients were less than 30 years and two patients were more than 30 years. Majority the patients are primigravida (4 out of 7 cases) and rest of the patients were one each in second, third and fourth gravida respectively. The mean gestational age is 34 weeks (range 24 to 38 weeks). One case was preterm gestation ( $<28$ weeks) and rest of the cases were term gestations (>28 weeks) as depicted in Figure 1.

Table: 1 Clinical parameter.

\begin{tabular}{|llllllll|}
\hline $\begin{array}{l}\text { Case } \\
\text { number }\end{array}$ & $\begin{array}{l}\text { Age } \\
\text { (years) }\end{array}$ & Gravida & $\begin{array}{l}\text { Gesta tional } \\
\text { age (weeks) }\end{array}$ & $\begin{array}{l}\text { Mode of } \\
\text { delivery }\end{array}$ & Indication & $\begin{array}{l}\text { Pregnancy } \\
\text { outcome }\end{array}$ & $\begin{array}{l}\text { Birth } \\
\text { weight (kg) }\end{array}$ \\
\hline 1 & 22 & 3 & 33 & $\begin{array}{l}\text { Emergency } \\
\text { LSCS }\end{array}$ & $\begin{array}{l}\text { Abruptio placenta } \\
\text { with cord presentation }\end{array}$ & $\begin{array}{l}\text { Alive and } \\
\text { poor apgar } \\
\text { score }\end{array}$ & 2 \\
\hline 2 & 35 & 2 & 24 & $\begin{array}{l}\text { Spontaneous } \\
\text { expulsion }\end{array}$ & $\begin{array}{l}\text { ?Acardiac twin with } \\
\text { placental solid tumour }\end{array}$ & $\begin{array}{l}\text { Intrauterine } \\
\text { foetal death }\end{array}$ & 0.7 \\
\hline 3 & 28 & 1 & 38 & $\begin{array}{l}\text { Emergency } \\
\text { LSCS }\end{array}$ & Fetal distress & $\begin{array}{l}\text { Alive and } \\
\text { healthy }\end{array}$ & 3 \\
\hline 4 & 34 & 4 & 35 & $\begin{array}{l}\text { Emergency } \\
\text { caesarean } \\
\text { hysterectomy }\end{array}$ & $\begin{array}{l}\text { Fetal distress / atonic } \\
\text { post partum }\end{array}$ & Alive and \\
hemorrhage & healthy & 3.5 \\
\hline 5 & 25 & 1 & 38 & $\begin{array}{l}\text { Labour } \\
\text { natural }\end{array}$ & Active labour & $\begin{array}{l}\text { Alive and } \\
\text { healthy }\end{array}$ & 3 \\
\hline 6 & 28 & 1 & 37 & $\begin{array}{l}\text { Labour } \\
\text { natural }\end{array}$ & Active labour & Dead born & 2.34 \\
\hline 7 & 27 & 1 & 38 & $\begin{array}{l}\text { Labour } \\
\text { natural }\end{array}$ & Active labour & $\begin{array}{l}\text { Alive and } \\
\text { healthy }\end{array}$ & 2.6 \\
\hline
\end{tabular}

Of the total seven cases, three patients delivered by labour natural, two patients by emergency LSCS, one patient by emergency LSCS with hysterectomy and one patient expelled spontaneously. The indications for emergency LSCS were fetal distress (case number 3), abruptio placenta (case number 1), fetal distress with atonic post partum haemorrhage (case number 4), one patient who expelled spontaneously was diagnosed as? acardiac twin with a solid placental mass (case number 2) and three patients were in active labour (case number 5, 6 and 7) who delivered by labour natural.
The pregnancy outcome was good (alive and healthy children) in five out of seven patients, one case had intrauterine death (case number 2) and another dead born (case number 6) as depicted in Figure 3. The birth weight was very low in one case, low birth weight in 2 children and normal birth weight in 4 children as depicted in Figure 4.

The gross features are summarised in Table 2. All the specimens received were complete placenta except case number 4 where in addition total abdominal hysterectomy with right salphingo oopherectomy specimen was received along with the placenta. On gross examination, 
lesions were intra placental in 4 cases and extra-placental in 3 cases (Figure 2). All lesions were solitary and the mean tumour size was $9 \mathrm{~cm}$ (range $5 \mathrm{~cm}$ to $15 \mathrm{~cm}$ ) and all lesions were large $(>5 \mathrm{~cm})$ as depicted in Figure 5. All tumours were nodular, well circumscribed solid masses.
Cut surface showed features of solid, firm, brownish, grey white, reddish brown to grey brown hemorrhagic masses as depicted in Figure 6. The umbilical cords and membranes were unremarkable.

Table 2: Gross features.

\begin{tabular}{|c|c|c|c|c|}
\hline $\begin{array}{l}\text { Case } \\
\text { number }\end{array}$ & Specimen submitted & $\begin{array}{l}\text { Size of the lesion } \\
\text { (largest dimension) }\end{array}$ & $\begin{array}{l}\text { Number } \\
\text { of lesions }\end{array}$ & Cut surface \\
\hline 1 & Placenta and an extraplacental solid mass & $10 \mathrm{~cm}$ & 1 & Solid, hemorrhagic \\
\hline 2 & Placenta and an extraplacental solid mass & $15 \mathrm{~cm}$ & 1 & $\begin{array}{l}\text { Grey white, firm, focal } \\
\text { hemorrhage }\end{array}$ \\
\hline 3 & Placenta with an intraplacental solid mass & $10 \mathrm{~cm}$ & 1 & $\begin{array}{l}\text { Grey white, } \\
\text { Focal blood filled spaces }\end{array}$ \\
\hline 4 & $\begin{array}{l}\text { Placenta and an extraplacental solid } \\
\text { mass, uterus, right tube, right ovary }\end{array}$ & $11 \mathrm{~cm}$ & 1 & $\begin{array}{l}\text { Solid, brownish, } \\
\text { Focal grey white areas. }\end{array}$ \\
\hline 5 & Placenta with an intraplacental solid mass & $8 \mathrm{~cm}$ & 1 & Solid, grey white \\
\hline 6 & Placenta with an intraplacental solid mass & $6 \mathrm{~cm}$ & 1 & $\begin{array}{l}\text { Solid, reddish brown, } \\
\text { hemorrhagic }\end{array}$ \\
\hline 7 & Placenta with an intraplacental solid mass & $5 \mathrm{~cm}$ & 1 & Grey brown , firm \\
\hline
\end{tabular}

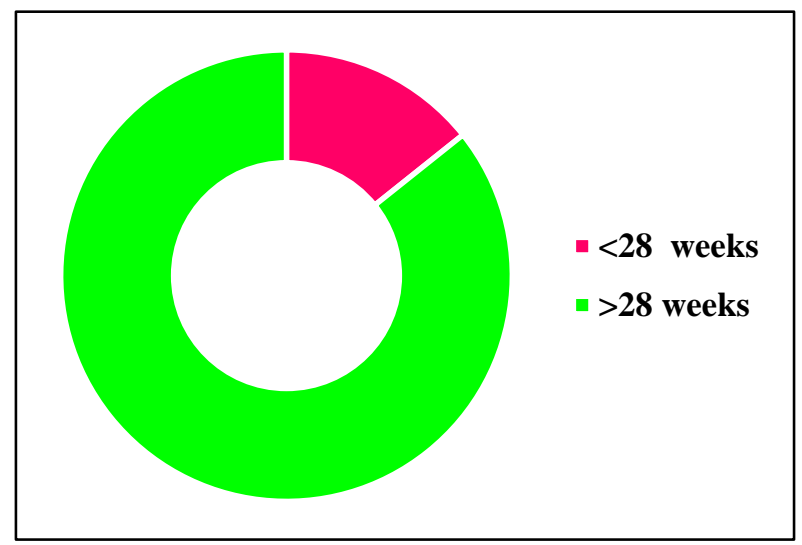

Figure 1: Gestational age.

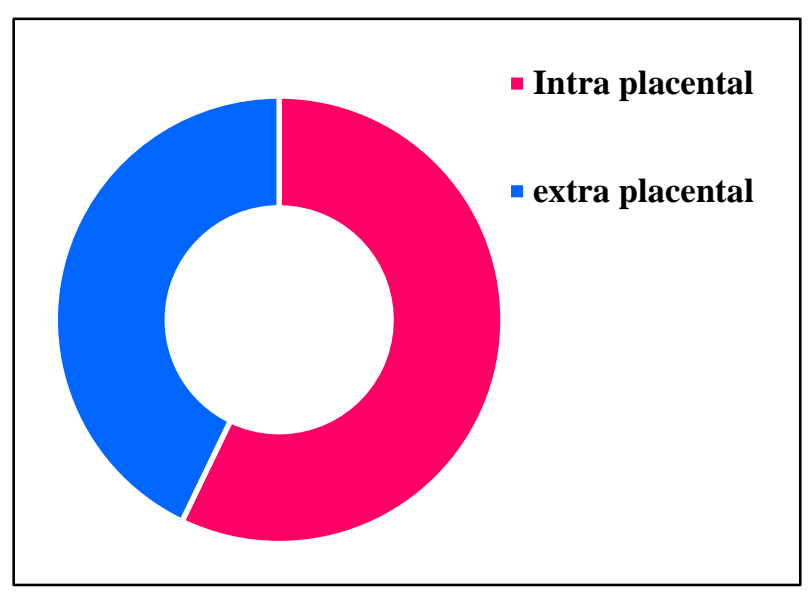

Figure 2: Location of the mass.

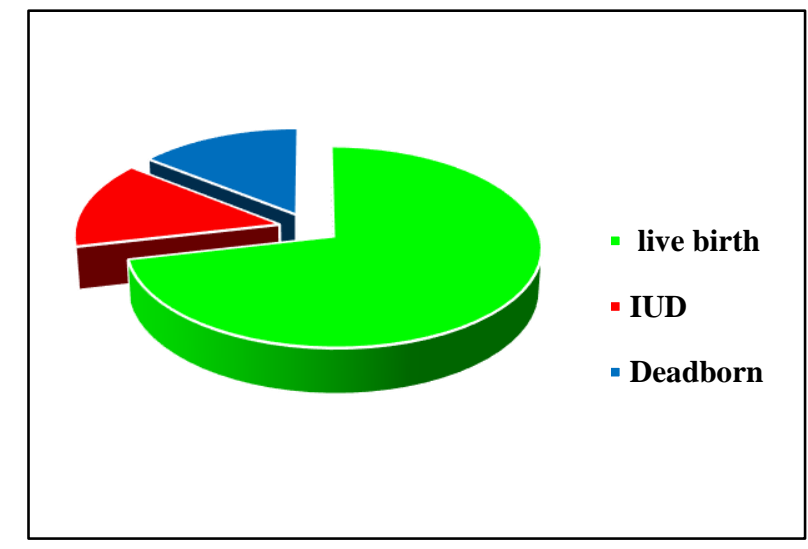

Figure 3: Fetal outcome.

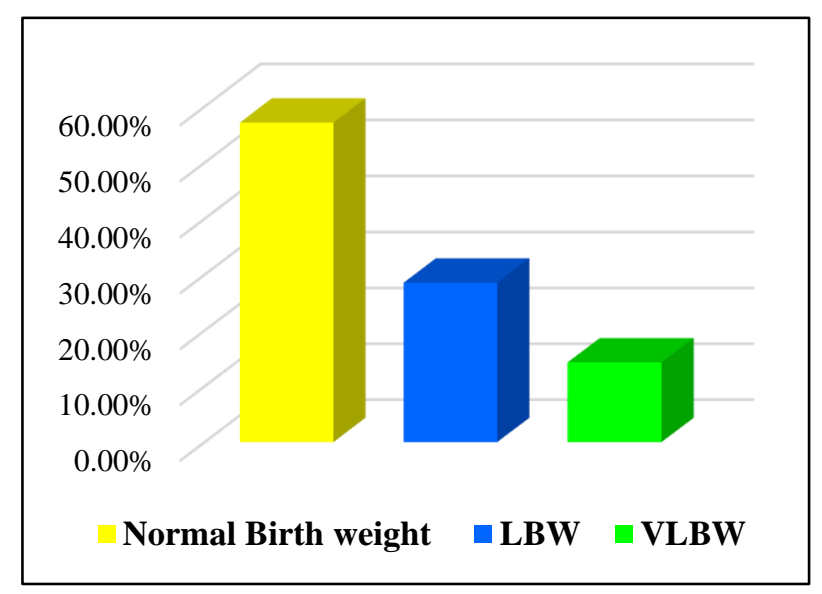

Figure 4: Birth weight 


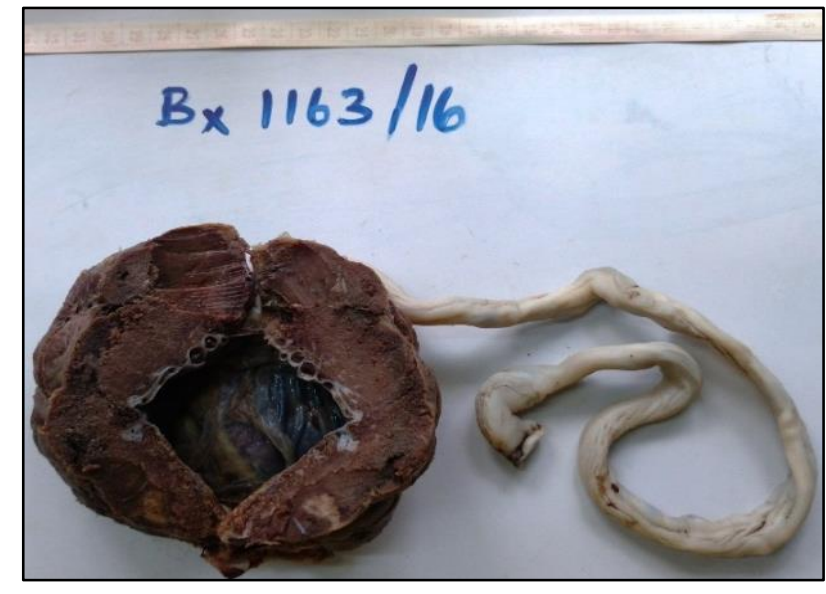

Figure 5: A circumscribed intraplacental mass adjacent to umbilical cord insertion.

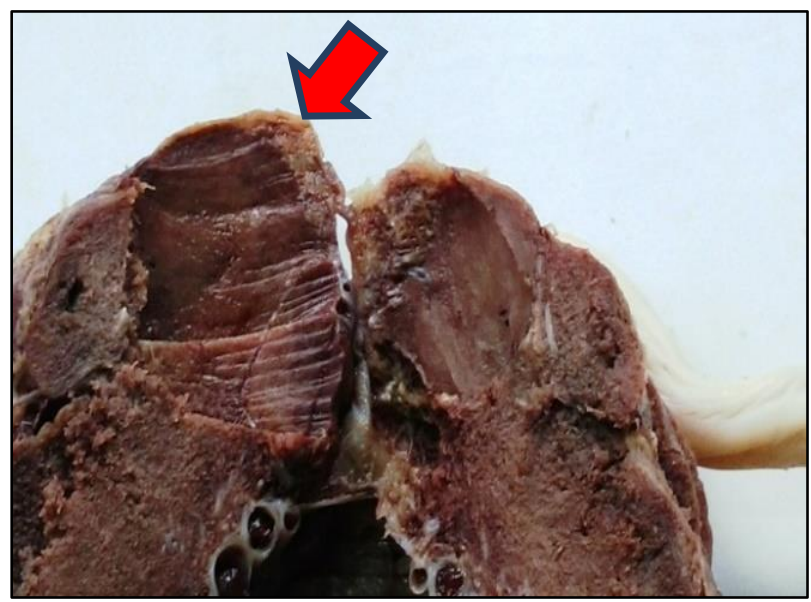

Figure 6: Intraplacental chorangioma is solid, firm and brown (arrow).

Data were analysed manually, looking at the frequency distribution of clinical parameters of the cases, fetal outcome, and the gross and microscopic features of the placenta submitted for histopathological examination.

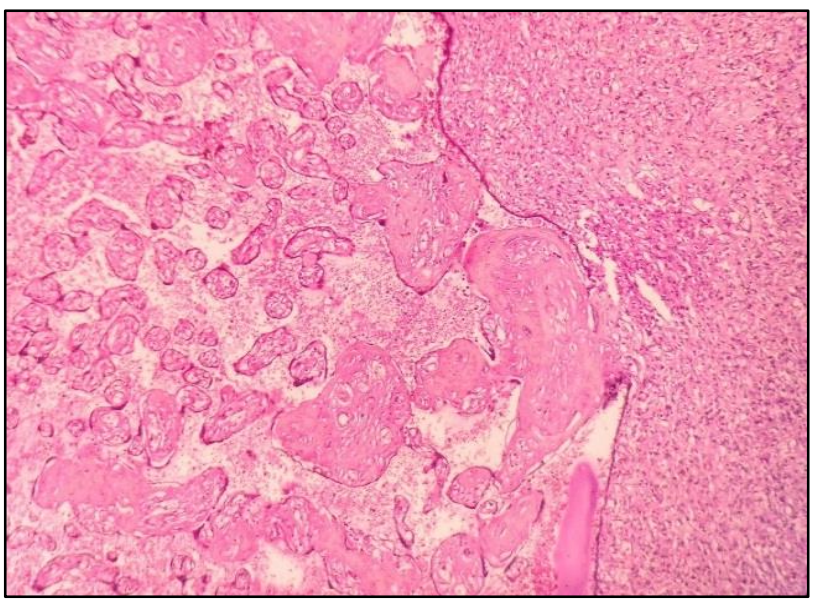

Figure 7:100x (H and E). Enlarged villi showing capillary proliferation.

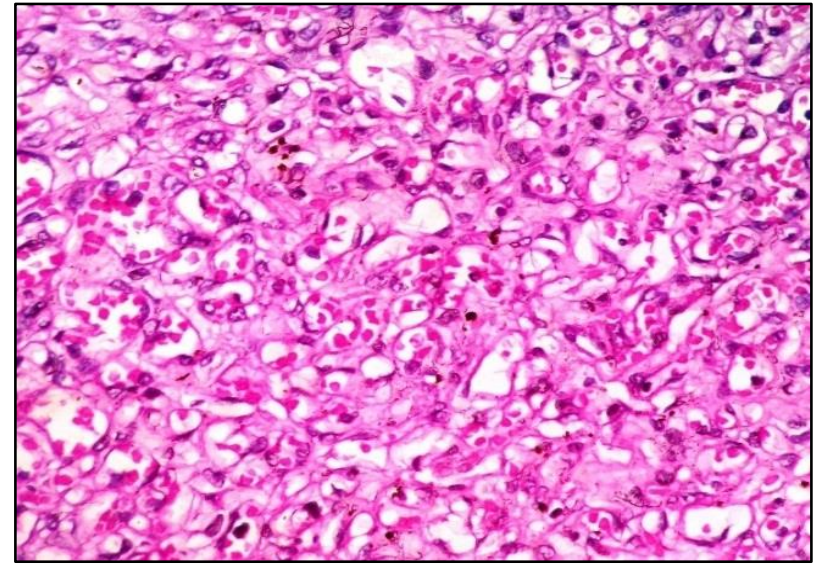

Figure 8:400x (H and E) Capillaries lined by flat endothelial cells containing RBCs

\section{DISCUSSION}

Chorangioma was first described as placental hemangioma by Clarke in $1798 .^{5}$ It is also referred to as placental angioma, chorioangioma, angiomyxoma or vascular hamartoma of the placenta. ${ }^{6}$ It is a benign, vascular, non trophoblastic neoplasm of the chorionic stroma. It is thought to arise from primitive mesenchymal chorionic tissue.,8 It is characterized by abnormal vascular proliferation within the parenchyma of the placenta. The reported incidence is $1 \%$ of all term placentas. It varies in size and number. The exact prevalence is often low as these lesions are usually small and undetectable unless a careful pathological examination of the placenta is carried out. ${ }^{9}$ Exact etiology is unknown and they are considered to be placental hamartomas.

They are often found in primipara and multiple gestations. Risk factors associated with the occurrence of chorangiomas include women over 30 years, diabetes and hypertension. ${ }^{8}$ The recurrence risk is not yet known. Examination of the placenta is essential, as the presence of chorangioma helps in elucidation of specific etiologies of abnormal pregnancies. It usually presents as a small intraplacental mass, uncommonly larger lesions (size $>5 \mathrm{~cm}$ ) which distort the chorionic plate of the placenta or even more rarely attached to the placenta by a thin vascular pedicle. The lesions are usually solitary and rarely multiple. Majority of these lesions are small and do not have any clinical significance. Chorangiomas are frequently seen intraplacentally below the chorionic plate adjacent to the insertion of the umbilical cord and may project into the amniotic cavity from the fetal surface.

Chorangioma arises from the stem villi and it is a potentially hazardous vascular lesion. It is clinically significant if the size is greater than $5 \mathrm{cms}$, which is then referred to as a giant chorangioma. Large chorangiomas are uncommon with an estimated incidence of 1:3500 and 1:16000 births. ${ }^{10}$ In India largest chorangioma which was reported weighed $2240 \mathrm{~g}^{2}$ In our study all the lesions 
were large $(>5 \mathrm{~cm})$ and the largest measured $15 \mathrm{~cm}$ which was associated with extremely preterm delivery at 24 weeks, very low birth weight $<0.7 \mathrm{~kg}$ and intra uterine fetal death in case number 2. Pathological examination of the placenta is considered as gold standard for confirmative diagnosis.

Literature review reveals a distinct relationship between chorangiomas and fetal, neonatal and maternal complications which include polyhydramnios, fetal anemia, thrombocytopenia, nonimmune hydrops, fetal heart failure, fetal cardiomegaly, fetal growth restriction, preterm delivery. ${ }^{11}$

Few authors have reported its association with maternal preeclampsia, which was apparent in our case number 1 . Fetal growth restriction is a cause of low birth weight, its relation to chorangioma has been documented in earlier studies. Chorangioma acts as a physiological dead space, resulting in chronic hypoxia leading on to fetal growth restriction. This explains the low birth weight in our cases number 1, 6 and very low birth weight in case number 2 and depicted in Figure 4. It is speculated, that placental tissue compensates for the foetal demands, thus decreasing the incidence of complications. Earlier studies have described the pathophysiology and pathogenesis of various complications associated with chorangioma. Pathophysiologically fetal heart failure can arise from increased blood flow through the low resistance vascular channels, fetal anemia and thrombocytopenia may occur due to sequestration of blood in the vascular mass and hydrops foetalis may result from microangiopathic haemolytic anaemia. ${ }^{3}$ Other complications include, polyhydramnios which may be related to fetal heart failure and ante partum haemorrhage, resulting from rupture of vascular pedicle.

Diagnosis can be made during the antenatal period by means of ultrasonogram if the lesions are more than $3 \mathrm{~cm}$ in size. ${ }^{4}$ Ultrasonogram shows an intraplacental, sub chorionic mass of mixed echogenicity than the surrounding placental parenchyma and often protrudes from the fetal surface of the placenta.

Grossly the tumours are usually well circumscribed, nodular masses found on the fetal surface of placenta near the insertion of the umbilical cord or within the placental parenchyma. The cut surface is variable and shows solid, firm, brown, yellow, tan, red or white masses. ${ }^{12}$ Myxoid areas and calcification can be seen.

Microscopically a well circumscribed, nodular neoplasm, exhibiting a diversity of angioblastemal differentiation with any of the three histological patterns namely angiomatous, cellular and degenerate. ${ }^{13}$ Angiomatous form is most common among the three and is composed of a network of proliferating capillary sized blood vessels causing enlargement of the chorionic villi. The capillaries are lined by flattened or plump endothelial cells. The vessels are separated by thin stroma composed of bland cells and collagen. Degenerative changes are common like myxoid change, hyalinisation, necrosis and calcification. $^{2}$ Mitoses may be present. $50 \%$ of cases can have extra villuos trophoblastic hyperplasia exhibiting nuclear atypia.

IHC may be helpful in diagnostically difficult cases. Positive staining for CD 31, CD 34 and focal staining for CK 18 suggest origin from blood vessels of chorionic plate and anchoring villi.

Macroscopic differential diagnosis include; 1) Hematoma 2) Placental Teratoma 3) Placental infarcts and 4) Intervillous thrombus. Microscopic differential diagnosis includes 1) Chorangiosis 2) Chorangiomatosis 3) Chorangicarcinoma. All these are villous capillary lesions. Chorangiosis involve terminal villi and the criteria for diagnosis are minimum 10 capillaries (vascular channels)/10 villi/10 low power fields. Chorangiomatosis involves intermediate villi and it does not form a discrete mass. This lesion permeates normal villi and is composed of proliferation of small capillaries surrounded by a continuous thick layer of pericytes which take up positive stain for smooth muscle actin (SMA) and stroma shows fibrosis. Chorangicarcinoma is a misnomer which shows features of trophoblastic proliferation adjoining the chorangioma.

Doppler and ultrasound imaging helps in prenatal diagnosis of chorangiomas. The different modalities of treatment are intrauterine transfusions through cordocentesis, amniodrainage for polyhydramnios and procedures to block arterio venous shunting which include endoscopic devascularization, alcoholic ablation and interstitial laser coagulation. ${ }^{14}$

\section{CONCLUSION}

As much of these lesions are overlooked, careful examination, sectioning of placenta and its histopathological examination are of utmost importance to match the reported incidence profile and will be helpful in surveillance of the mother and neonate for infrequently associated complications especially in a tertiary care obstetrics and gynaecology hospital.

\section{Funding: No funding sources \\ Conflict of interest: None declared}

Ethical approval: The study was approved by the Institutional Ethics Committee

\section{REFERENCES}

1. Wallenburg HCS. Chorangioma of the placenta: thirteen new cases and a review of the literature from 1939 to 1970 with special reference to clinical complications. Obstet and Gynecol Survey. 1971;26:411-25.

2. Bagga R, Suri V, Srinivasan R, Chadha S, Chopra S, Gupta N. Huge placental myxoid chorangioma 
presenting with severe antepartum hemorrhage. JNMA J Nepal Med Assoc. 2006;45:366-9.

3. Kurman RJ. Blaustein's Pathology of the Female Genital Tract. 5th ed. Springer: New York; 2002.

4. Shafgat G, Iqbal F, Rizvi F. Chorangioma of the Placenta with hydrops Foetalis. JPMA. 2009;59:4112.

5. Jaffe R, Siegal A, Rat L, Bernheim J, Gruber A, Fejgin M. Placental chorioangiomatosis - a high risk pregnancy. Postgrad Med J. 1985;61:453-5.

6. Andola US, Karangadan S, Andola SK, Jewargikar R. Chorangioma of placenta with high risk pregnancy: A case series. J Basic Clin Rep Sci. 2014;3:71-3.

7. Gruca-Stryjak K, Ropacka-Lesiak M, Bręborowicz GH. Nontrophoblastic placental tumors. Arch Perinatal Med. 2011;17(2):113-7.

8. Lez C, Fures R, Hrgovic Z, Belina S, Fajdic J, Munstedt K. Chorangioma placentae. Rare Tumors. 2010;2(4).

9. Guschmann M, Henrich W, Entezami $M$ and Dudenhausen JW. Chorioangioma- new insights into a well-known problem. Results of a clinical and morphological study of 136 cases. Journal of Perinatal Medicine. 2003;31(2):163-9.
10. Esen UI, Orife SU and Poland K. Placental Chorangioma: A case report and review of literature. British Journal of Clinical Practice. 1997;51(3):1812.

11. Fox H, Sebire NJ. Non Trophoblastic Tumours of Placenta In: Fox H. Pathology of the placenta. $2^{\text {nd }}$ Ed. Philadelphia: Saunders Elsevier; 2007:401-430.

12. Baergen RN. Neoplasms. In: Baergen RN. Manual of Benirscke Kauffman's pathology of the Human Placenta. New York: Springer; 2005:405-415.

13. Marchetti AA. A consideration of certain types of benign tumours of the Placenta, Surgery Gynaecology and Obstetrics. 1939;68:733-743.

14. Zanardini C, Papageorghiou A, Bhide A, Thilaganathan B. Giant placental chorioangioma: Natural history and pregnancy outcome. Ultrasound Obstet Gynecol. 2010;35:332-6.

Cite this article as: Balamurugan $\mathrm{V}$, Revathy $\mathrm{M}$, Kanchana MP, Shobha S. Large chorangiomas: a seven years study in a tertiary care obstetrics and gynaecology hospital. Int J Reprod Contracept Obstet Gynecol 2019;8:1967-72. 